Transactions of the American Fisheries Society 127:995-1005, 1998

(C) Copyright by the American Fisheries Society 1998

\title{
The Influence of Spawning Habitat on Natural Reproduction of Muskellunge in Wisconsin
}

\author{
SARAH A. ZORN \\ University of Michigan, School of Natural Resources and Environment \\ Ann Arbor, Michigan 48109-1115, USA \\ Terry L. Margenau \\ Wisconsin Department of Natural Resources, 810 West Maple, Spooner, Wisconsin 54801, USA \\ JAMES S. DianA* \\ University of Michigan, School of Natural Resources and Environment \\ Clayton J. Edwards \\ U.S. Department of Agriculture, Forest Service, North Central Forest Experiment Station \\ 5985 County Highway K, Rhinelander, Wisconsin 54501, USA
}

\begin{abstract}
Many of Wisconsin's native populations of muskellunge Esox masquinongy exhibit declining reproductive success and failing natural recruitment. As a result, self-sustaining populations of muskellunge are diminishing. This study focused on spawning habitat factors that influence egg development and survival and, consequently, the reproductive success of muskellunge. Muskellunge spawning habitat characteristics in lakes with self-sustaining populations were compared with spawning habitat characteristics in lakes that were once self-sustaining but are now maintained by stocking. The hatching success of artificially fertilized eggs was assessed under natural lake conditions. Spawning sites were typically marshy areas in water less than $1 \mathrm{~m}$ deep. Characteristics of the spawning habitat influenced successful reproduction. Spawning areas in stocked lakes had low dissolved oxygen (DO; $1.2-5.4 \mathrm{mg} / \mathrm{L}$ ) at the substrate-water interface, whereas self-sustaining lakes had more variable DO $(0.5-9.6 \mathrm{mg} / \mathrm{L})$ with some microhabitats having high DO. Organic carbon content, texture of spawning substrate, and water temperature at the substrate did not differ between self-sustaining lakes and lakes supported by stocking. Fallen logs, stumps, and other wood in spawning areas may increase egg survival. Muskellunge egg survival over natural substrate was low $(0.0-1.3 \%)$, even in lakes with self-sustaining populations. Collections of eggs and observations of fry indicated that major mortality occurred after egg deposition but before fry reached nursery habitats several weeks after hatching.
\end{abstract}

\section{Introduction}

Many of Wisconsin's populations of native muskellunge Esox masquinongy exhibit declining reproductive success and failing natural recruitment (Dombeck et al. 1986; Hanson et al. 1986). As a result of decreasing natural reproduction, many populations are now supplemented or completely supported by stocking. In Wisconsin's inland waters, only $18 \%$ of muskellunge populations are considered self-sustaining (WDNR 1996).

The decline in natural reproduction of muskellunge has been explained in several ways: (1) competition with northern pike E. lucius for food and spawning grounds (Oehmcke et al. 1958; Inskip 1986); (2) overharvest (Hanson 1986); (3) failure to protect females until first spawning with an appropriate size limit (Hanson 1986); (4) quantity

\footnotetext{
*Corresponding author: jimd@umich.edu
}

and size of food available to fry (Oehmcke et al. 1958); (5) water temperature and water level during spawning (Oehmcke et al. 1958); (6) predation on fry by fish and invertebrates (Oehmcke et al. 1958; Scott and Crossman 1973; Porter 1977); and (7) loss or alteration of spawning habitat (Trautman 1981; Dombeck et al. 1984; Dombeck et al. 1986).

This study addressed the hypothesis that declining muskellunge populations are a result of spawning habitat loss or alteration. Previous studies indicated the importance of muskellunge spawning habitat (Trautman 1981; Dombeck et al. 1984; Dombeck et al. 1986), but detailed knowledge of habitat requirements for early life stages is incomplete. Spawning traits of muskellunge allow a greater impact of habitat on egg survival than some other reproductive tactics. In general, muskellunge spawn in shallow bays $(<1 \mathrm{~m})$ over mucky bottoms with much debris and dead veg- 
etation (Oehmcke et al. 1958; Scott and Crossman 1973; Porter 1977; Dombeck 1979). Nonadhesive eggs are broadcast in a spawning area and settle to the lake bottom (Scott and Crossman 1973; Hess and Hartwell 1978). In about 2 weeks, larvae hatch and remain inactive at the bottom for another 10 d until yolk sac absorption; they do not swim up and attach to vegetation as do larvae of other esocids (Scott and Crossman 1973; Dombeck et al. 1984). These traits suggest habitat during embryonic development may be critical to reproductive success.

Our study examined the influence of spawning habitat on muskellunge reproductive success. We studied muskellunge spawning and early life history in four lakes, two with self-sustaining muskellunge populations and two that were once selfsustaining but are now maintained by stocking. Lakes were evaluated to (1) identify preferred muskellunge spawning sites, (2) determine characteristics of spawning habitats that support successful muskellunge reproduction, (3) assess hatching success of artificially fertilized and incubated eggs under natural lake conditions, and (4) observe fry and their habitat and examine yearclass strength of natural muskellunge the following fall.

\section{Methods}

Study lakes and spawning areas.-Four lakes were selected in northwest Wisconsin, two with good levels of natural reproduction and two with poor levels. Mineral (91 ha) and Lower Clam (93 ha) lakes have good levels of natural reproduction; the muskellunge population is self-sustaining (no stocking has occurred in these lakes since 1976 and 1970, respectively). Brunet Flowage (51 ha) and Lac Courte Oreilles (2,039 ha) have poor levels of natural reproduction, and the population is supported by stocking. Work was conducted on Mineral and Lower Clam lakes in 1994 and on all four lakes in 1995, unless otherwise noted.

We had difficulty finding lakes with poor natural reproduction that met our requirements. We wanted lakes that had a self-sustaining population before natural reproduction declined and lakes without northern pike. Declining natural reproduction and the need for stocking to maintain the population was determined by lake managers, though often there is not a clear record of when the decline occurred. Even though Brunet Flowage is now an impoundment, historically there was a reproductively successful population of muskellunge that spawned in a wide part of the river, though it is not known if reproduction has been successful since impoundment. Because Lac Courte Oreilles is a large lake, we used only its Musky Bay (surface area, 93 ha; maximum depth, $5.8 \mathrm{~m}$ ), a major muskellunge spawning area (Johnson 1981), as our study area. Lac Courte Oreilles does have a northern pike population, but Lyons and Margenau (1986) found that naturally reproduced muskellunge did not decline as northern pike increased in Lac Court Oreilles, suggesting that the influence of northern pike on muskellunge reproduction may be minimal in this lake.

Muskellunge spawning sites were determined visually and verified by collection of naturally spawned eggs. Visual observations were conducted by boat at night with the aid of spotlights and were made inshore in less than $1 \mathrm{~m}$ of water. $\mathrm{Ob}$ servations began half an hour after sunset and continued until the entire shoreline had been surveyed, which was never later than 0100 hours. Spawning areas were determined as shoreline areas where muskellunge congregated.

After a spawning area had been delineated and spawning completed (early May), we searched for eggs. Dip nets were used to collect bottom substrate, which was then sorted by hand. Egg searches in Mineral and Lower Clam lakes were conducted in 1994; searches in Lac Courte Oreilles and Brunet Flowage were done in 1995. Numbers of live and dead eggs were recorded in the field, and eggs were examined under a microscope to determine development. All eggs were apparently from muskellunge.

Spawning habitat characteristics.-Four main components of spawning habitat were examined: (1) dissolved oxygen (DO) at the substrate-water interface, (2) organic matter content of substrate, (3) texture of substrate (percent of sand, silt, and clay), and (4) water temperature $\left({ }^{\circ} \mathrm{C}\right)$. In addition, we visually estimated percent of spawning area covered by woody debris, measured water velocity in spawning areas, and monitored lake water levels.

Dissolved oxygen was measured in spawning areas during egg development between 0400 and 0600 hours when DO levels would be lowest. Measurements were made with a YSI 54A dissolved oxygen meter that was calibrated before each day of use and attached to a $1.5-\mathrm{m}$-tall stand so readings could be collected at known distances above bottom. In spawning areas, 10 sites/lakes were randomly selected for DO measurements. At each site, DO readings were taken at 0,5 , and $10 \mathrm{~cm}$ above the substrate in $30-90 \mathrm{~cm}$ of water. 
In 1994, water temperatures were recorded in Lower Clam and Mineral lakes. One thermograph was placed in a spawning area in each lake shortly after spawning began (26-28 April) and was removed after eggs began hatching (14-16 May). In 1995 , temperatures were recorded continuously in all four lakes from before spawning (28 April-4 May) until eggs began hatching (14-22 May) with StowAway WT56-8K temperature recorders. Ten recorders were placed in each lake; six in spawning areas and four in other areas of the lake. Recorders were secured to a 1-m metal stake and placed between $1 \mathrm{~m}$ and $4 \mathrm{~m}$ from shore in $30-90 \mathrm{~cm}$ of water. The stake and recorder were placed horizontally on lake bottom so temperatures were recorded where muskellunge eggs develop.

Water velocity in spawning areas was measured in all lakes in 1995 shortly before spawning began with a Marsh McBirney 201D portable current meter (detection limit $0.01 \mathrm{~m} / \mathrm{s}$ ). Velocity samples were taken at 10 locations per lake. At each sample location, velocity was measured with the probe facing north, south, east, and west.

In 1994, there was a dramatic change in water level during spawning and egg incubation that we felt might impact egg survival. In 1995, water level fluctuations were monitored from spawning until egg hatching by means of stakes marked with the prespawning water level that were placed in each study lake. Water level changes were recorded as a rise or drop from that prespawning water level.

For the remainder of habitat work, about 10 transects were established in each spawning area (Lower Clam and Mineral lakes in 1994 and Lac Courte Oreilles and Brunet Flowage in 1995). Transects, which were $2 \mathrm{~m}$ wide and extended 10 $\mathrm{m}$ perpendicular from shore, were spread evenly through the spawning area. Three habitat components were recorded along each transect: (1) organic matter content of substrate, (2) texture of substrate, and (3) surface area of wood in the transect (visually estimated). A substrate sample, consisting of three replicate collections mixed to form a composite sample, was collected at random along each transect. Samples were dried and later analyzed in the laboratory for organic matter and texture. Percent organic matter in the substrate was determined by the Walkley-Black method (Nelson and Sommers 1982). Texture characteristics were determined by the hydrometer method of particle size analysis (Gee and Bauder 1986). We followed a modified form of this analysis (Stoyenoff et al. 1995).

Egg hatching success.-Adult muskellunge were collected from each lake with fyke nets, and eggs were stripped and fertilized from multiple spawners. All eggs from a lake were combined, and some were placed back in the lake in containers to evaluate natural hatching success. Remaining eggs were incubated at the Arthur A. Oehmcke Hatchery in Woodruff, Wisconsin, to verify that eggs were viable.

In 1994, fertilized eggs were held in coneshaped containers $(38 \mathrm{~cm}$ tall, 15-cm-diameter base) made of mesh $(8 \times 8$ squares $/ \mathrm{cm})$. The chamber bottom was open so eggs were on natural substrate, and the top was cinched closed around a center anchoring stake. Ten and 15 chambers, respectively, were spaced evenly in spawning areas in Lower Clam and Mineral lakes. Degree days were used to estimate hatching time; muskellunge eggs hatch after experiencing about 180 degree days (Westers and Stickney 1993). Chambers were removed several days after we expected eggs had hatched, and the contents were examined in the field or laboratory.

In 1995, fertilized eggs were placed in containers constructed from green plastic 19-L buckets. Four rectangular holes $(15 \times 23 \mathrm{~cm})$ were cut in the sides and a circular hole $(21 \mathrm{~cm}$ diameter $)$ in the lid, and holes were covered with aluminum window screen $(6 \times 7$ squares $/ \mathrm{cm})$. Three types of treatments were used in the buckets: substrate (10 buckets/lake), wood (3 buckets/lake) and suspended ( 5 buckets/lake). For substrate treatments, substrate was gently scooped into the bucket until it was filled with $5-10 \mathrm{~cm}$ of substrate. For wood treatments, wood was obtained from Mineral Lake, sawed into square sections, and scored with a screwdriver, creating a rough surface that prevented eggs from easily rolling off. A slab of wood was then placed in a bucket on $5-10 \mathrm{~cm}$ of substrate. Suspended treatments had a mesh screen inside the bucket about $16 \mathrm{~cm}$ above bottom so eggs would be in the lake, but not on the substrate. This was done to test water quality effects rather than sediment effects on survival.

In all, 18 buckets were placed evenly throughout the spawning areas in each lake. Buckets were placed in 30-90 cm of water, settled $5-10 \mathrm{~cm}$ into the substrate, and anchored to a stake. Wood treatments were placed next to a substrate treatment, but all other buckets were placed individually. They were positioned without lids and allowed to settle for several days before eggs were introduced and lids were attached. About 300 fertilized eggs, estimated volumetrically, were dispersed by hand into each bucket. Bucket screens remained rela- 
tively clear for the 2-3 weeks they were in the lakes, so we concluded that water exchange was good and that conditions inside buckets were similar to surrounding habitat.

As in 1994, degree days were used to estimate hatching time. Temperature data from Lac Courte Oreilles was used for calculating degree days in all lakes. Several days after we expected that eggs had hatched, buckets were removed from the lakes and transported to the laboratory in containers filled with water, so that the contents would not dry out. Contents were sorted within $24 \mathrm{~h}$. A bucket was placed into a sugar solution, and fry and eggs that floated were removed (Anderson 1959). Remaining contents were sorted manually three times for eggs, fry, and invertebrates, which were preserved in alcohol. Eggs and fry were counted, and any development in unhatched eggs was determined according to Galat (1973).

Age-O fish.-We searched for naturally hatched fry with dip nets and seines $(1 \times 4.5 \mathrm{~m}, 0.08-\mathrm{cm}$ mesh). Searches were made in and near known spawning areas, where we expected fry would be. Fry were measured for total length, and water depth and vegetation at their location were recorded. Sampling was conducted about every 3 weeks from early June until August.

Relative year-class strength was determined from fall electrofishing conducted after dark with a bow mount AC electrofishing boat. Sampling occurred after water temperatures had fallen to approximately $10^{\circ} \mathrm{C}$ (usually mid-October to early November). One complete circuit of electrofishing around the shoreline was conducted on Lower Clam Lake, Mineral Lake, and Brunet Flowage. In Lac Courte Oreilles, a circuit of electrofishing was conducted around the shoreline of Musky Bay.

Data analysis.-The SPSS computer software package was used for most statistical analyses (Norusis 1993). Analysis of variance (ANOVA) procedures were used to compare spawning habitat characteristics among the four study lakes. When assumptions of normality and equal variance were met, ANOVA was followed by a Bonferroni multiple-range test. When assumptions were not met, data were transformed (with natural log or square root) before ANOVA, which was followed by a Bonferroni or a Duncan multiple-range test. If assumptions were not met even after transformation, data were analyzed with a nonparametric, Kruskal-Wallis one-way ANOVA followed by a nonparametric analog of Fisher's least significant difference multiple-range test (calculated by hand). Hypotheses were tested with an alpha of 0.05 .
Repeated-measures ANOVA procedures were used to compare daily mean temperatures and daily temperature fluctuations among study lakes from 29 April to 15 May 1995. Within each lake, daily mean temperatures and daily temperature fluctuations were compared between spawning and nonspawning areas.

A two-way ANOVA was used to compare percent egg survival in buckets among the four study lakes and among the three treatment types (SYSTAT:Wilkinson 1989). Small sample size was taken into account in selecting statistical tests. Egg survival data were transformed with the arcsine transformation,

$x^{\prime}=(n+0.5)^{1 / 2} \operatorname{arcsine}[(x+0.375) /(n+0.75)]^{1 / 2}$,

where $x / n$ is the data as a proportion (Zar 1974), but assumptions of normality and equal variances were still not met.

\section{Results}

\section{Spawning Habitat Characteristics}

Two major spawning areas were identified in Lower Clam Lake and in Mineral Lake; one spawning area was identified in Musky Bay and in Brunet Flowage (Zorn 1996). Spawning sites were marshy, with soft substrate covered by dead vegetation in water less than $1 \mathrm{~m}$ deep. Naturally spawned eggs were collected shortly after spawning began; 46 eggs were found in Lower Clam Lake, 21 eggs in Mineral Lake, 19 eggs in Lac Courte Oreilles, and 15 eggs in Brunet Flowage. In Lower Clam and Mineral lakes, eggs were less than $3 \mathrm{~d}$ old, and about $70 \%$ were alive at collection. However, in Lac Courte Oreilles and Brunet Flowage, eggs were about $5 \mathrm{~d}$ old, and $3 \%$ were alive.

The spawning area in Lac Courte Oreilles was initially identified incorrectly based on observations before spawning began. Observations conducted $4 \mathrm{~d}$ later showed pairs of muskellunge concentrated farther in Musky Bay, and this spawning location was verified by collection of eggs. However, by this time, experimental buckets had been placed in the wrong area. Data collected outside the true spawning area were not used in analyzing spawning habitat characteristics nor in analyzing egg survival among lakes, but survival results are provided.

At the substrate-water interface, median DO values in spawning areas were generally low (Table 1). Mineral Lake had significantly higher DO than Lower Clam Lake and Lac Courte Oreilles, 
TABLE 1.- Ranges (medians) for dissolved oxygen levels at 0,5 , and $10 \mathrm{~cm}$ above substrate in muskellunge spawning areas in study lakes and means (SDs) for percent of organic carbon, texture of spawning substrate, and spawning area covered by wood. Values along rows followed by a common letter are not significantly different (alpha $=0.05$ ).

\begin{tabular}{|c|c|c|c|c|c|}
\hline Variable & $\begin{array}{c}\text { Lower Clam } \\
\text { Lake }\end{array}$ & $\begin{array}{l}\text { Mineral } \\
\text { Lake }\end{array}$ & $\begin{array}{c}\text { Lac Courte } \\
\text { Orielles }\end{array}$ & $\begin{array}{l}\text { Brunet } \\
\text { Flowage }\end{array}$ & $P$ \\
\hline \multicolumn{6}{|c|}{ Dissolved oxygen (mg/L) } \\
\hline $0 \mathrm{~cm}$ & $0.5-9.1 \quad(1.5) \mathrm{y}$ & $0.6-9.6(6.0) \mathrm{z}$ & $1.2-5.4(1.4) \mathrm{y}$ & $1.4-4.4(1.8) \mathrm{zy}$ & $0.039^{\mathrm{a}}$ \\
\hline $5 \mathrm{~cm}$ & $4.7-10.6(8.2) \mathrm{z}$ & $3.7-9.8(8.3) \mathrm{zx}$ & $1.3-8.8(1.5) \mathrm{y}$ & $2.0-8.3(7.6) \mathrm{yx}$ & $0.011^{\mathrm{a}}$ \\
\hline $10 \mathrm{~cm}$ & $7.0-10.6(8.7) \mathrm{z}$ & $3.7-9.8(8.6)$ zy & $1.9-8.8(3.5) \mathrm{y}$ & $7.6-8.5(8.1) \mathrm{zy}$ & $0.047^{\mathrm{a}}$ \\
\hline Organic carbon $(\%)$ & $24.6(8.1) \mathrm{z}$ & $13.9(12.3) \mathrm{y}$ & $17.3(15.7) \mathrm{zy}$ & $21.8(8.7)$ zy & $0.000^{\mathrm{a}}$ \\
\hline \multicolumn{6}{|l|}{ Texture $(\%)$} \\
\hline Sand & $19.6(19.1) \mathrm{y}$ & $41.5(29.6) \mathrm{z}$ & $40.4(35.0) \mathrm{zy}$ & 23.4 (14.9) zy & $0.006^{\mathrm{a}}$ \\
\hline Silt & $73.9(18.1) \mathrm{z}$ & $55.4(28.8)$ y & $51.9(34.2) \mathrm{zy}$ & $69.6(13.7) \mathrm{zy}$ & $0.033^{\mathrm{a}}$ \\
\hline Clay & $6.4(6.0) \mathrm{z}$ & $3.1(3.8) \mathrm{y}$ & $7.7(5.4) \mathrm{zy}$ & $7.1(6.6) \mathrm{zy}$ & $0.036^{\mathrm{b}}$ \\
\hline Wood $(\%)$ & $3.2(4.8)$ & $7.7(23.0)$ & $0.1(0.3)$ & $1.9(1.8)$ & $0.150^{\mathrm{c}}$ \\
\hline
\end{tabular}

a Kruskal-Wallis one-way analysis of variance (ANOVA) followed by nonparametric analog of Fisher's least-significant-difference multiple-range test.

b One-way ANOVA with $\log _{e}$-transformed data followed by Duncan's multiple-range test.

c Kruskal-Wallis one-way ANOVA.

but no other comparison among lakes was significant. Lower Clam and Mineral lakes had large variation in DO levels; some areas within spawning sites had high DO. Lac Courte Oreilles and Brunet Flowage showed less variation and had low DO in the entire spawning area. At $5 \mathrm{~cm}$ above the substrate, Lower Clam Lake had significantly higher DO than Lac Courte Oreilles and Brunet Flowage, and Mineral Lake had significantly higher DO than Lac Courte Oreilles but not Brunet Flowage. Mineral and Lower Clam lakes had less variation in DO at $5 \mathrm{~cm}$ than stocked lakes, which still had some areas where DO was low. At $10 \mathrm{~cm}$ above the substrate, median oxygen concentration was higher in all lakes. Lower Clam Lake had a significantly higher DO concentration than Lac Courte Oreilles. Only Lac Courte Oreilles still had areas where DO was low. All lakes showed DO stratification; DO was lower at the substrate-water interface than $10 \mathrm{~cm}$ above the substrate.

Organic carbon content of spawning substrate ranged from 14 to $25 \%$ (Table 1). Organic carbon was not significantly different among lakes, except between Mineral (14\%) and Lower Clam lakes $(25 \%)$.

All lakes had similar substrate texture and low clay content (Table 1). Lower Clam Lake had a significantly higher percentage of silt and clay and a correspondingly lower percentage of sand in its spawning substrate than Mineral Lake. No other comparison among lakes was significant.

In 1994, spawning area temperatures in Lower Clam and Mineral lakes were similar and rose from $6^{\circ} \mathrm{C}$ on 30 April to $14^{\circ} \mathrm{C}$ on 13 May and dropped $2-3^{\circ} \mathrm{C}$ on 14 and 15 May before warming to $14^{\circ} \mathrm{C}$ on 16 May. In 1995, spawning area temperatures were similar in all four lakes, rising from an average $9^{\circ} \mathrm{C}$ on 29 April to $13-16^{\circ} \mathrm{C}$ on 6 May and then dropping $4-6^{\circ} \mathrm{C}$ from 6 May to 8 May before increasing to about $14^{\circ} \mathrm{C}$ by 14 May. Daily highs in Brunet Flowage were often $1-3^{\circ} \mathrm{C}$ cooler and temperatures in Lac Courte Oreilles were $1-3^{\circ} \mathrm{C}$ warmer than those in Lower Clam and Mineral lakes. All study lakes showed a daily temperature change of $3-7^{\circ} \mathrm{C}$.

Daily mean temperatures during spawning and egg incubation were not significantly different in spawning areas among study lakes or between spawning and nonspawning areas within a lake, except in Lower Clam Lake, where the relationship between temperature and day was different in spawning and nonspawning areas. Daily temperature fluctuations in spawning areas were not significantly different among lakes. There were no significant differences in temperature fluctuation between spawning and nonspawning areas within a lake, except in Lower Clam Lake, where temperature fluctuations between spawning and nonspawning areas were different for different days.

Amount of wood present in spawning areas was not significantly different among lakes (Table 1). The high mean in Mineral Lake was partially attributed to one sampling location, in which the bottom was entirely covered with old wood slabs that came from a former sawmill.

Water velocities in spawning areas were low, although there was some water movement. Velocity was higher in all directions (north, south, east and west) in Lower Clam Lake (mean, 0.032$0.038 \mathrm{~m} / \mathrm{s}$ ) than in the other lakes, where velocity was less than $0.01 \mathrm{~m} / \mathrm{s}$ (the detection limit of the current meter). Meter readings taken in Lower 
TABLE 2.- Means (SD) for survival to hatching of muskellunge eggs and recovery of dead eggs from bucket chambers for three treatment types in each lake and survival to hatching of hatchery-incubated eggs in 1995.

\begin{tabular}{|c|c|c|c|c|}
\hline \multirow{2}{*}{$\begin{array}{l}\text { Lake and } \\
\text { variable }\end{array}$} & \multicolumn{3}{|c|}{ Treatment } & \multirow[b]{2}{*}{ Hatchery } \\
\hline & Substrate & Wood & Suspended & \\
\hline \multicolumn{5}{|l|}{ Lower Clam Lake } \\
\hline Survival (\%) & $0.03(0.11)$ & $0.22(0.39)$ & $7.20(14.29)$ & 84 \\
\hline Recovery (\%) & 36.2 (8.27) & $23.6 \quad(20.98)$ & $60.0 \quad(44.57)$ & \\
\hline \multicolumn{5}{|l|}{ Mineral Lake } \\
\hline Survival (\%) & $0.03(0.11)$ & $2.56(4.43)$ & $24.53(20.12)$ & 93 \\
\hline Recovery (\%) & $43.4(17.16)$ & $26.2(16.68)$ & $37.6 \quad(26.70)$ & \\
\hline \multicolumn{5}{|c|}{ Lac Courte Oreilles } \\
\hline Survival (\%) & $0.80(1.49)$ & $1.67(2.33)$ & $4.47(3.76)$ & 80 \\
\hline Recovery (\%) & $17.8(9.67)$ & $19.5(13.50)$ & 29.7 (19.07) & \\
\hline \multicolumn{5}{|l|}{ Brunet Flowage } \\
\hline Survival (\%) & $0.13(0.42)$ & 0.00 & $3.67(6.25)$ & 92 \\
\hline Recovery (\%) & $31.8 \quad(11.67)$ & $43.3 \quad(35.04)$ & $59.5 \quad(22.75)$ & \\
\hline
\end{tabular}

Clam Lake did not stabilize but varied over a range of values, indicating turbulent water movement.

Water level in all lakes fluctuated somewhat during spawning and egg incubation, with fluctuations generally following rainfall patterns. In 1995, water levels decreased through April, increased in mid May following several rainstorms, and decreased again through the end of May. Mineral Lake fluctuated the most (about $30 \mathrm{~cm}$ ). Lower Clam Lake fluctuated less than $8 \mathrm{~cm}$, Brunet Flowage about $13 \mathrm{~cm}$, and Lac Courte Oreilles less than $5 \mathrm{~cm}$. In 1994, water levels in Mineral Lake rose about $30 \mathrm{~cm}$ before egg chambers were placed in the lake. When chambers were removed about 3 weeks later, water level had dropped $58 \mathrm{~cm}$.

\section{Egg Hatching Success}

In 1994, when eggs were incubated in mesh chambers, no fry were found, and all recovered eggs were dead. None of the dead eggs developed past day 7 , and $98 \%$ had not developed past day 3. Eggs were known to be viable because hatcheryincubated eggs showed $70-100 \%$ survival to hatching.

In 1995, with bucket incubation, egg hatching was more successful, but survival was still low and highly variable (Table 2). Hatchery-incubated eggs showed $80-93 \%$ survival to hatching, so eggs were viable. Higher survival in substrate treatments in Lac Courte Oreilles was probably a result of buckets being placed outside the spawning area when it was initially identified incorrectly. Lac Courte Oreilles egg survival results were not used in statistical analysis.

For Lower Clam Lake, Mineral Lake, and Brunet Flowage combined, eggs in suspended treatments had a significantly higher percent survival $(11.81 \%)$ than eggs in wood $(0.93 \%)$ or substrate
$(0.05 \%)$ treatments. Over all bucket treatment types, egg survival in Mineral Lake was significantly higher than in Brunet Flowage, but no other comparison among lakes showed significant differences.

Even though buckets were designed to increase egg recovery over mesh chambers by using a completely enclosed container, there was still low and variable recovery of dead eggs (Table 2). No estimate of sampling error was made, but as there was $100 \%$ recovery in some buckets and sorting was done thoroughly, we probably recovered a high percentage of dead eggs that were present in buckets. Fungus growth was common on dead eggs, making some counting difficult. Development of eggs before death varied from only several days to almost hatching, although most had not developed past day 9 .

\section{Collection of Age-O Fish}

Young fry were more readily found in self-sustaining lakes than in lakes supported by stocking, which suggests that most mortality occurred before muskellunge fry reached nursery habitat (Table 3 ).

Nursery habitats were generally shallow areas (25-50 cm deep), in or near spawning sites. Fry were mainly observed near vegetation, $2-5 \mathrm{~cm}$ below the surface. Vegetation commonly included hardstem bulrushes Scirpus actus, sedges Carex sp., yellow water lilies Nuphar sp., wild celery Vallisneria americana, bigleaf pondweed Potamogeton amplifolius, flatstem pondweed Potamogeton zosteriformis, and fernleaf pondweed Potamogeton richardsonii.

Fall electrofishing data indicated low relative abundance of age- 0 muskellunge in Lac Courte Oreilles and Brunet Flowage, with higher relative abundance in Mineral and Lower Clam lakes (Ta- 
TABLE 3.-Number of age-0 muskellunge collected from June until August and catch per effort (CPE) and historical CPE of age-0 muskellunge from fall electrofishing runs.

\begin{tabular}{|c|c|c|c|}
\hline \multirow[b]{2}{*}{ Lake and year } & \multirow[b]{2}{*}{$\begin{array}{l}\text { Number } \\
\text { collected }\end{array}$} & \multicolumn{2}{|c|}{ Fall electrofishing } \\
\hline & & $\begin{array}{c}\mathrm{CPE} \\
\text { (fish/hr) }\end{array}$ & $\begin{array}{c}\text { Historical } \\
\text { CPE }^{\mathrm{a}} \\
\text { (fish/hr) }\end{array}$ \\
\hline \multicolumn{4}{|l|}{ Lower Clam Lake } \\
\hline 1994 & 4 & 2.0 & 1.4 \\
\hline 1995 & 0 & 1.8 & \\
\hline \multicolumn{4}{|l|}{ Mineral Lake } \\
\hline 1994 & 35 & 22.9 & 3.3 \\
\hline 1995 & 12 & 2.4 & \\
\hline \multicolumn{4}{|l|}{ Lac Courte Orielles } \\
\hline 1995 & $2^{b}$ & 0 & $0.3^{b}$ \\
\hline \multicolumn{4}{|l|}{ Brunet Flowage } \\
\hline 1995 & 0 & 0.6 & c \\
\hline
\end{tabular}

a Average from available fall shocking data, 1985-1993.

${ }^{b}$ May include stocked fry.

${ }^{\mathrm{c}}$ No data.

ble 3). No historical data were available for Brunet Flowage. Catch per unit effort (CPE) in Lower Clam and Mineral lakes was similar to historical CPEs, except that CPE in Mineral Lake was extremely high in 1994. In spring 1994, about 30 adult muskellunge were transferred, before spawning, into Mineral Lake from a nearby lake and their offspring may have contributed to the extra large year-class.

\section{Discussion}

Muskellunge egg survival until hatching was low, even in lakes with self-sustaining populations. Bucket incubation results indicated that reproductive success may always be low for muskellunge. In Lower Clam Lake, Mineral Lake, and Brunet Flowage, eggs in substrate and wood treatments averaged $99.7 \%$ mortality. High mortality early in life is typical of broadcast spawners that exhibit no parental care (Hjort 1914; Carbine 1944; Dahlberg 1979). Even a low egg survival rate may be adequate to replace adult stock, as adult muskellunge densities are also low. Little information is available on adult densities of unstocked muskellunge populations and stocking may create artificially high densities. Studies in stocked and unstocked lakes have shown that adult densities range from 0.02 to 0.38 muskellunge/ha, but even with stocking, adult densities greater than 0.4 muskellunge/ha have not been reported (Eddy and Underhill 1974; Johnson 1981; Hanson 1986; Margenau and AveLallemant 1993). However, small decreases in already low egg survival may be enough to inhibit natural muskellunge reproduction in a lake.

Substantial mortality of muskellunge in study lakes apparently occurred after egg deposition but before fry reached nursery habitat several weeks after hatching. In muskellunge, the life stage of highest mortality is unknown, although it is thought to be in the first year of life (Dombeck 1986). In this study, naturally spawned eggs were recovered from all lakes; egg deposition occurred even in lakes supported by stocking. Eggs collected in 1994 in self-sustaining lakes had 30\% mortality $3 \mathrm{~d}$ after fertilization; those collected in 1995 in stocked lakes showed $97 \%$ mortality 5-6 $\mathrm{d}$ after fertilization. It is difficult to tell if differences are due to differences between years, between lakes, or between age at collection. No attempts were made to collect naturally spawned eggs after verifying spawning areas or to collect eggs in nonspawning areas. Several weeks after hatching, naturally reproduced fry could be found in self-sustaining lakes but not in Brunet Flowage, though one was found during fall electroshocking, and fry found in Lac Courte Oreilles may be from stocking. These findings suggest most mortality occurs during egg development or shortly after hatching.

Some habitat components did not appear to cause declining muskellunge populations. Characteristics, such as percent organic carbon and texture of spawning substrate, were similar in both self-sustaining and stocked lakes. Percent organic carbon (14-25\%) was comparable to amounts found in muskellunge spawning areas in other lakes (11-40\%) (Dombeck et al. 1984).

Mean daily temperature and daily temperature fluctuations in spawning areas were also similar for all study lakes. Other aspects of temperature, such as severe drops, may be more critical for eggs and fry. In 1994, after egg chambers were placed in the lakes, there was a drastic drop in temperature. Daily high air temperature dropped from $23^{\circ} \mathrm{C}$ on 24 April to $4^{\circ} \mathrm{C}$ on 28 April, when water temperature in Mineral Lake was $3^{\circ} \mathrm{C}$. This temperature change may have killed many eggs and, if so, it explains why no fry were recovered from chambers. In 1995, a temperature drop was also recorded. It occurred later and was not as severe as in 1994, and there was survival in buckets. We did not test the temperature tolerance of eggs, but other studies show muskellunge eggs and fry are sensitive to water temperature fluctuations (Bean 1908; Oehmcke et al. 1958). Hatchery studies indicate that abnormally low temperatures produce 
weak fry and high mortalities (Klingbiel and Oehmcke 1957). Water temperatures below $10^{\circ} \mathrm{C}$ delay development (Johnson 1958), and fry maintained at $7^{\circ} \mathrm{C}$ show disrupted physiological processes, incomplete development, and $75 \%$ mortality by day 35 (Hassan and Spotila 1976).

Hatching in buckets indicated that eggs survived better off the substrate (in suspended treatment) than directly on lake bottom. Dombeck et al. (1984) incubated eggs in the laboratory over different substrate types. They found that eggs incubated on leaves and macrophytes showed 99 and $76 \%$ mortality, respectively, within $2 \mathrm{~d}$, which was attributed to low DO $(0.0-0.1 \mathrm{mg} / \mathrm{L})$. Oxygen levels were higher over wood $(1.3 \mathrm{mg} / \mathrm{L})$ than over silt $(0.2 \mathrm{mg} / \mathrm{L})$ but were highest over sand, gravel, polyethylene screen, and glass (3.8-4.1 mg/L). Within the first several days, lowest egg mortality occurred on organic substrates, such as silt and wood, that had intermediate DO and that limited fungal infestation because substrates provided some physical separation of eggs.

We are confident that spawning areas were identified correctly because naturally spawned muskellunge eggs were found in all areas, verifying visual observations. In Lac Courte Oreilles, the spawning area was first identified incorrectly, but later observations and egg collections indicated the correct location. Though every spawning area may not have been identified, muskellunge were spawning in areas where data were collected and additional areas would probably have been similar to those identified. Spawning areas were similar to spawning sites reported in other studies (Oehmcke et al. 1958; Scott and Crossman 1973; Porter 1977; Dombeck 1979).

Dissolved oxygen in spawning areas differed significantly between self-sustaining and stocked lakes. Lakes supported by stocking had consistently low DO at the substrate-water interface, whereas self-sustaining lakes had more variable DO. Spawning areas of self-sustaining lakes had regions where DO was inadequate for egg survival but also had regions where DO was high. Eggs that settle in a high DO microhabitat would have adequate oxygen and a better chance of survival. Because lakes supported by stocking lacked areas of higher DO, all eggs had inadequate oxygen for development. Possibly, having microhabitats with high DO determines whether a lake will support successful reproduction.

Dissolved oxygen levels in spawning areas may be critical for reproductive success, especially because muskellunge lack means of avoiding low DO at the substrate (Dombeck et al. 1984; Clapsadl 1993). Dombeck et al. (1984) examined DO in muskellunge spawning areas in the field and concluded that low DO levels contributed to egg mortality and could be a limiting factor to reproduction. They found that lakes with self-sustaining populations had high DO values (mean, 6.0-8.4 $\mathrm{mg} / \mathrm{L}$ ) at the substrate-water interface and little DO microstratification. On the other hand, lakes supported by stocking had low DO values (mean, $0.4-2.4 \mathrm{mg} / \mathrm{L}$ ) at the substrate-water interface and extreme DO microstratification. In the present study, similar low DO levels were found at the substrate of lakes supported by stocking. However, in spawning areas of self-sustaining lakes, DO at the substrate was generally low, with only small pockets of high DO. High DO at the spawning substrate in self-sustaining lakes may not be as uniform as the data of Dombeck et al. indicated. Differences between studies may be from DO measurement techniques. In the present study, DO was measured with a DO meter at 0,5 , and $10 \mathrm{~cm}$ above bottom. Dombeck et al. (1984) used a dialysis tube method that measured DO at $1-16 \mathrm{~mm}(8 \mathrm{~mm}$ average) and $0-100 \mathrm{~mm}$ (50 $\mathrm{mm}$ average) above the substrate-water interface. They also had a larger sample of study lakes.

Literature addressing minimum oxygen tolerances for muskellunge eggs and sac fry is limited to the implications of the study of Dombeck et al. (1984). The first days of embryonic development can progress with DO as low as $0.2 \mathrm{mg} / \mathrm{L}$. In northern pike, tolerance to low DO decreased from embryo to larva (Peterka and Kent 1976), and this may occur in muskellunge as well. Survival of northern pike embryos in 8 -h exposure to $0.6 \mathrm{mg} /$ $\mathrm{L}$ was the same as at high DO, while yolk sac larvae survival declined at DO levels below 2.0 $\mathrm{mg} / \mathrm{L}$, and larvae survival declined below $4.0 \mathrm{mg} /$ L. Dissolved oxygen levels below 33\% saturation (about $3.2 \mathrm{mg} / \mathrm{L}$ ) were inadequate for northern pike survival from embryo to first feeding (Siefert et al. 1973). Naturally occurring oxygen concentrations in muskellunge spawning areas are frequently lower than concentrations reported necessary for survival of northern pike eggs and larvae.

Self-sustaining lakes had a higher percentage of their spawning area covered by wood than stocked lakes. Also, in buckets, survival to hatching was higher in wood than in substrate treatments. Even though these findings were not statistically significant, we feel wood in spawning areas is important to successful muskellunge reproduction. 
Wood at the substrate may keep eggs from sinking into sediments and suffocating. Death of fertilized eggs has been partially attributed to smothering when eggs sink into the substrate (Schneberger 1936). Wood can provide a better habitat for egg development by supporting eggs higher in the water column, where DO levels are higher. Muskellunge prefer to spawn in areas of submerged wood, where logs, stumps, and driftwood are most concentrated (Nevin 1901; Leach 1927; MacGregor et al. 1960).

Fluctuations in lake levels during spawning and egg development occurred to different extents in study lakes. Water level changes can be critical for muskellunge, especially if levels drop and expose developing eggs to air. In 1994, in Mineral Lake, several chambers were stranded on land when water levels dropped $0.5 \mathrm{~m}$ after chambers were placed in the lake. Stranding of muskellunge eggs and young has been observed in other studies (Scott and Crossman 1973).

Mineral Lake had the greatest daily water level changes in 1994 and 1995 but also had the most fry during fall electroshocking surveys. Water levels were only monitored during spawning and egg incubation, so yearly patterns of water level change were not available. Though daily fluctuations impact egg survival, long-term fluctuations may also be important. Certain annual patterns of water level change, such as spring flooding, may benefit muskellunge reproductive success. Rising spring water levels have been associated with successful reproduction and are common to lakes maintaining self-sustaining populations of muskellunge (Dombeck et al. 1986).

The dam built on Brunet River in the 1960s that created Brunet Flowage may have negatively impacted the muskellunge population by eliminating natural spring flooding or by covering previous spawning areas with deep water. Muskellunge benefit from rising spring water levels, but stabilized water levels appear to be detrimental (Dombeck et al. 1986). In Ohio, muskellunge were successful in reproducing in streams that widely overflowed in spring (Trautman 1981). In a Kentucky study, impoundments on five streams were considered responsible for declining muskellunge populations (Axon and Kornman 1986). Muskellunge may also benefit from decreased water levels over winter. Reservoirs in which water levels were drawn down at least $2 \mathrm{~m}$ each winter and restored in early spring, supported self-sustaining muskellunge populations (Dombeck et al. 1984; Dombeck et al. 1986), and high hatching success has been docu- mented when the substrate was aerated by a winter drawdown (Dombeck et al. 1984). Fluctuations that expose bottom sediments are thought to desiccate and consolidate organic material, aerate substrates that have a high biochemical oxygen demand, and consolidate highly aqueous substrates, forming a firmer substrate (Kadlec 1962; Dunst et al. 1974) that may improve muskellunge spawning habitat (Dombeck 1986).

Four of six spawning areas identified in study lakes were associated with inlet streams; the other two were adjacent to wetlands, typically groundwater discharge areas. Water movement may increase egg or larval survival if flow is enough to increase DO in areas that would otherwise have insufficient oxygen levels. Higher and more turbulent water velocities recorded in Lower Clam Lake may contribute to the reproductive success of the muskellunge population in that lake. Muskellunge often prefer riverine spawning conditions and may be best adapted for life in flowing waters (Crossman 1978; Harrison and Hadley 1978; Lebeau and Pageau 1989). Dombeck et al. (1984) found that small influent streams were present near spawning areas in several of their study lakes and hypothesized that adult muskellunge may respond to inflowing water when searching for a spawning location. Statistical analysis of 117 lakes in Michigan, Minnesota, and Wisconsin indicated that a high lake discharge volume was common to selfsustaining muskellunge lakes (Dombeck et al. 1986).

Future muskellunge management must recognize the importance of spawning habitat to muskellunge reproductive success. Protection of spawning areas is critical. Acquisition of land adjacent to spawning areas and passage of laws moderating shoreline alterations can help to preserve such habitats. Also, it is necessary to identify lakes with self-sustaining muskellunge populations so they can be protected. In choosing study lakes, it was difficult to determine which lakes contained self-sustaining populations because many lakes were stocked without a good understanding of the levels of natural reproduction. Part of this problem stems from lack of information about adult densities in self-sustaining populations.

Management efforts to increase DO in spawning areas may enhance natural reproduction. Dredging, bottom sealing, and placement of sand and gravel in a spawning area have been proposed to increase DO and create a firmer substrate (Born et al. 1973; Dunst et al. 1974; Dombeck et al. 1984; Dombeck 1986). These alterations can be costly, 
disruptive to the lake ecosystem, and may not succeed because muskellunge do not naturally spawn over sand and gravel. Placing wood in spawning areas may be a more feasible management tool for improving natural reproduction (Dombeck et al. 1984; Dombeck 1986). Appropriate forest management that allows riparian trees to die naturally could be a feasible means of recruiting wood into lakes. Removing woody debris, especially in spawning areas, probably has a negative impact on the muskellunge fishery as well as on other fish species. Reproduction may also be improved by restoring or imitating natural water level fluctuations. Winter drawdown followed by spring flooding has been suggested as a way of improving muskellunge spawning habitat (Dombeck 1986). Water level management in impoundments can provide beneficial seasonal water level changes while eliminating daily fluctuations that can strand eggs. Management must also keep in mind that reproductive success is probably always low for muskellunge and that natural reproduction will produce low adult densities.

\section{Acknowledgments}

This study was a cooperative effort between the University of Michigan, Wisconsin Department of Natural Resources, and the U.S. Department of Agriculture, Forest Service. Funding was provided by the U.S. Department of Agriculture, Forest Service, North Central Forest Experiment Station, cooperative project 23-93-43, Federal Aid in Sport Fish Restoration Act, grant F-95-P, and Wisconsin Department of Natural Resources.

\section{References}

Anderson, R. O. 1959. A modified flotation technique for sorting bottom fauna samples. Limnology and Oceanography 4:223-225.

Axon, J. R., and L. E. Kornman. 1986. Characteristics of native muskellunge streams in eastern Kentucky. Pages 263-272 in Hall (1986).

Bean, T. H. 1908. The muskalonge [sic] of the Ohio basin. Transactions of the American Fisheries Society 37:145-151.

Born, S. M., T. L. Wirth, E. M. Brick, and J. O. Peterson. 1973. Restoring the recreational potential of small impoundments. Wisconsin Department of Natural Resources, Technical Bulletin 71, Madison.

Carbine, W. F. 1944. Egg production of the northern pike Esox lucius L., and the percentage survival of eggs and young on the spawning grounds. Papers of the Michigan Academy of Science, Arts, and Letters 29:123-137.

Clapsadl, M. D. 1993. An examination of habitat characteristics influencing the survival of stocked mus- kellunge, Esox masquinongy, in four St. Lawrence river embayments. Master's thesis. State University of New York, College of Environmental Science and Forestry, Syracuse.

Crossman, E. J. 1978. Taxonomy and distribution of North American Esocids. Pages 13-26 in R. L. Kendall, editor. Selected coolwater fishes of North America. American Fisheries Society, Special Publication 11, Bethesda, Maryland.

Dahlberg, M. D. 1979. A review of survival rates for fish eggs and larvae in relation to impact assessments. U.S. National Marine Fisheries Service Marine Fisheries Review 41(3):1-12.

Dombeck, M. P. 1979. Movement and behavior of the muskellunge determined by radio telemetry. Wisconsin Department of Natural Resources, Technical Bulletin 113, Madison.

Dombeck, M. P. 1986. Muskellunge habitat with guidelines for habitat management. Pages 208-215 in Hall (1986).

Dombeck, M. P., B. W. Menzel, and P. N. Hinz. 1984. Muskellunge spawning habitat and reproductive success. Transactions of the American Fisheries Society 113:205-216.

Dombeck, M. P., B. W. Menzel, and P. N. Hinz. 1986. Natural muskellunge reproduction in Midwestern lakes. Pages 122-134 in Hall (1986).

Dunst, R. C., and nine coauthors. 1974. Survey of lake rehabilitation techniques and experiences. Wisconsin Department of Natural Resources, Technical Bulletin 75, Madison.

Eddy, S., and J. C. Underhill. 1974. Northern fishes. University of Minnesota Press, Minneapolis.

Galat, D. L. 1973. Normal embryonic development of the muskellunge (Esox masquinongy). Transactions of the American Fisheries Society 102:384-391.

Gee, G. W., and J. W. Bauder. 1986. Particle-size analysis. Pages 283-311 in A. Klute, editor. Methods of soil analysis. Part 1, 2nd edition. Number 9. American Society of Agronomy, Inc. and Soil Science Society of America, Inc., Madison, Wisconsin.

Hall, G. E., editor. 1986. Managing muskies. American Fisheries Society, Special Publication 15, Bethesda, Maryland.

Hanson, D. A. 1986. Population characteristics and angler use of muskellunge in nine northern Wisconsin lakes. Pages 238-248 in Hall (1986).

Hanson, D. A., and five coauthors. 1986. Improving musky management: a review of management and research needs. Pages 335-341 in Hall (1986).

Harrison, E. J., and W. F. Hadley. 1978. Ecologic separation of sympatric muskellunge and northern pike. Pages 129-134 in R. L. Kendall, editor. Selected coolwater fishes of North America. American Fisheries Society, Special Publication 11, Bethesda, Maryland.

Hassan, K. C., and J. R. Spotila. 1976. The effect of acclimation on the temperature tolerance of young muskellunge fry. Pages 136-140 in G. W. Esch and R. W. McFarlane, editors. Thermal ecology II: proceedings of a symposium held at Augusta, Georgia, April 2-5, 1975. Energy Research and Development 
Administration, Technical Information Center, Oak Ridge, Tennessee.

Hess, L., and C. Hartwell. 1978. Literature review of large esocids (muskellunge, northern pike and hybrid tiger muskellunge). Pages 139-175 in J. Dube and Y. Gravel, editors. Proceedings of the 10th warmwater workshop. American Fisheries Society, Northeastern Division, Bethesda, Maryland.

Hjort, J. 1914. Fluctuation in the great fisheries of northern Europe viewed in the light of biological research. Rapports et Proces-Verbaux des Reunions Conceil International pour L'Exploration de la Mer 20:1-228.

Inskip, P. D. 1986. Negative associations between abundances of muskellunge and northern pike: evidence and possible explanations. Pages 135-150 in Hall (1986).

Johnson, L. D. 1958. Pond culture of muskellunge in Wisconsin. Wisconsin Conservation Department, Technical Bulletin 17, Madison.

Johnson, L. D. 1981. Comparison of muskellunge populations in a stocked lake and unstocked lake in Wisconsin, with notes on the occurrence of northern pike. Wisconsin Department of Natural Resources, Research Report 110, Madison.

Kadlec, J. A. 1962. The effects of drawdown on a waterfowl impoundment. Ecology 43:267-281.

Klingbiel, J. H., and A. A. Oehmcke. 1957. A closed circuit battery for the incubation and hatching of muskellunge and sucker eggs. Wisconsin Conservation Department, Northeast Area Fish Management Division, Investigational Memorandum 1, Rhinelander.

Leach, G. C. 1927. Artificial propagation of pike perch, yellow perch and pikes. U.S. Bureau of Fisheries, Document 1018, Washington, D.C.

Lebeau, B., and G. Pageau. 1989. Comparative urogenital morphology and external sex determination in muskellunge, Esox masquinongy Mitchell. Canadian Journal of Zoology 67:1053-1060.

Lyons, J., and T. L. Margenau. 1986. Population dynamics of stocked adult muskellunge (Esox masquinongy) in Lac Court Oreilles, Wisconsin 19611977. Wisconsin Department of Natural Resources, Technical Bulletin 160, Madison.

MacGregor, J., J. Scott, and B. Dean. 1960. A review of the life history and proposed management of the northern muskellunge (Esox m. immaculatus). Michigan Department of Conservation, Fish Division, Lake and Stream Improvement Report 100, Ann Arbor.

Margenau, T. L., and S. AveLallemant. 1993. Evaluation of a 40-inch size limit for muskellunge in Wisconsin. Progress Report, Study 629, Spooner, Wiscon$\sin$.

Nelson, D. W., and L. E. Sommers. 1982. Organic car- bon and organic matter. Pages 561-579 in A. L. Page, editor. Methods of soil analysis, part 2, number 9, 2nd edition. American Society of Agronomy, Inc. and Soil Science Society of America, Inc. Madison, Wisconsin.

Nevin, J. 1901. The propagation of muskellunge in Wisconsin. Transactions of the American Fisheries Society 30:90-93.

Norusis, M. J. 1993. SPSS. SPSS Inc., Chicago.

Oehmcke, A. A., L. Johnson, J. Klingbiel, and C. Wistrom. 1958. The Wisconsin muskellunge - its life history, ecology and management. Wisconsin Conservation Department, Publication 225, Madison.

Peterka, J. J., and J. S. Kent. 1976. Dissolved oxygen, temperature, survival of young at fish spawning sites. U.S. Environmental Protection Agency, EPA600/3-76-113, Washington, D.C.

Porter, L. R. 1977. Review of selected literature on muskellunge life history, ecology and management. Minnesota Department of Natural Resources, Special Publication 119, St. Paul.

Schneberger, E. 1936. Spawning habits of the muskellunge. Wisconsin Conservation Department, Unpublished Report, Madison.

Scott, W. B., and E. J. Crossman. 1973. Freshwater fishes of Canada. Fisheries Research Board of Canada Bulletin 184.

Siefert, R. E., W. A. Spoor, and R. F. Syrett. 1973. Effects of reduced oxygen concentrations on northern pike (Esox lucius) embryos and larvae. Journal of the Fisheries Research Board of Canada 30:849852 .

Stoyenoff, J. L., J. A. Witter, and B. A. Leutscher. 1995. Protocol handbook for the Michigan impact monitoring system. Michigan Cooperative Forest Pest Management Program, Handbook 95-1, Lansing.

Trautman, M. B. 1981. The fishes of Ohio, revised edition. Ohio State University Press, Columbus.

WDNR (Wisconsin Department of Natural Resources). 1996. Wisconsin muskellunge waters. WDNR Publication RS-919-96, Madison.

Westers, H., and R. R. Stickney. 1993. Northern pike and muskellunge. Pages 199-213 in R. R. Stickney, editor. Culture of nonsalmonid freshwater fishes, 2nd edition. CRC Press, Ann Arbor, Michigan.

Wilkinson, L. 1989. SYSTAT: the system for statistics. SYSTAT, Evanston, Illinois

Zar, J. H. 1974. Biostatistical analysis. Prentice-Hall, Englewood Cliffs, New Jersey.

Zorn, S. A. 1996. The influence of spawning habitat on natural reproduction of muskellunge in Wisconsin. Master's thesis. University of Michigan, School of Natural Resources and Environment, Ann Arbor.

Received December 19, 1996 Accepted February 24, 1998 